\title{
Pedagogiske betraktninger rundt utvikling av en digital læringsressurs
}

Rigmor Furu

Digital læring er kommet for å bli i høyere utdanning, og studentene etterspør flere fleksible og digitale læringsressurser. Dette kapittelet handler om pedagogiske valg og didaktiske vurderinger i utvikling av den digitale læringsressursen «Inter-Dig». Hvordan utvikle en digital læringsressurs for helsefagstudenter som skal lære tverrprofesjonelt samarbeid? Hvilke pedagogiske overveielser tas ved valg av innhold, digitale verktøy og arbeidsformer? I kapittelet diskuteres også hvorfor casebasert læring egner seg godt til å lære tverrprofesjonelt samarbeid, og betydningen av studentinvolvering og lærerens digitale kompetanse i utviklingen.

\section{Innledning}

Dette kapittelet handler om hvordan den digitale læringsressursen Inter-Dig ble utviklet fra start til ferdig læringsressurs, med fokus på pedagogiske og didaktiske muligheter og utfordringer. Kapittelet hører sammen med kapittelet «Studentenes erfaringer fra deltakelse i en digital læringsressurs om tverrprofesjonelt samarbeid». Prosjektet Inter-Dig, en digital læringsressurs om tverrprofesjonell samarbeidslæring (TPS), var en del av Fyrtårnprosjektet ved Det helsevitenskapelige fakultet (Helsefak) ved UiT Norges arktiske universitet (Hauksdottir \& Iversen, 2020). Jeg var prosjektleder for InterDig. Prosjektet ble gjennomført i tidsrommet 2018-2019 og prøvd ut våren 2019, se prosjektbeskrivelse og sluttrapport (Furu, 2018, 2019). 
Digitalisering i høyere utdanning beskrives i strategi ved Det helsevitenskapelige fakultet (Helsefak) ved UiT Norges arktiske universitet som at Helsefak vil «skape engasjerende og tidsriktige utdanningstilbud» og «legge til rette for fleksible og nettstøttede undervisningsformer» (Strategi Helsefak UiT ut mot 2022). Prosjektet Inter-Dig er også helt i tråd med Digitaliseringsstrategi for universitets- og høyskolesektoren (2017-2021), som sier at «Kvalitetsmeldingens krav er at alle studenter skal møte læringsformer der digitale muligheter utnyttes». Hensikten med Inter-Dig var å tilby alle helsefagstudenter en fleksibel og interaktiv læringsressurs om tverrprofesjonell samarbeidslæring som kunne gjennomføres underveis i studieløpet. Prosjektet Inter-Dig skulle utvikle, prøve ut og evaluere en digital læringsressurs om tverrprofesjonell samarbeidslæring i læringsplattformen Canvas. Læringsressursen ble utviklet i tett samarbeid mellom fagansatte og studenter ved UiT Norges arktiske universitet.

Digital læring er for fullt kommet inn i høyere utdanning, ikke minst for å møte studentenes forventninger om tilgang til digitale plattformer og digitale læringsressurser, og muligheten for å lære uavhengig av tid og sted. Educause Horizon Report (2019) for høyere utdanning har sett på innovasjon og nye trender i høyere utdanning når teknologi innføres, og utfordrer oss til å tenke nytt om hvordan undervisning, læring og vurdering organiseres og gjennomføres. Rapporten framhever at vi beveger oss mot studentsentrerte undervisningsformer der studenten tar og har større kontroll over egen læring, og der lærerrollen i større grad utøves gjennom å veilede, motivere og tilrettelegge. Trenden går mot mer mobil læring og blanda læringsformer (blended learning) i tillegg til å lære gjennom virtuell virkelighet og kunstig intelligens (Alexander, AshfordRowe, Barajas-Murphy et al., 2019). Digitaliseringen stiller således krav til digital kompetanse hos både undervisere og studenter i høyere utdanning.

Nasjonale retningslinjer for helse- og sosialfagutdanningene (RETHOS) har utarbeidet minstestandarder for sluttkompetansebeskrivelser for samtlige grunnutdanninger innen helse- og sosialfagene (Kunnskapsdepartementet, 2017). Ifølge felles læringsutbytte 12 (RETHOS) skal studenten oppnå sluttkompetansen «Har digital kompetanse og kan bistå utviklingen av og bruke egnet teknologi både på individ- og systemnivå» (Kunnskapsdepartementet, 2017). Digitale ferdigheter handler om å innhente og behandle informasjon, være kreativ og skapende med digitale ressurser og det å samhandle og kommunisere med andre i digitale omgivelser. Digitale ferdigheter innebærer å ha kunnskap om digital sikkerhet og utvikle digital dømmekraft ved å tilegne seg kunnskap og gode strategier for nettbruk (Utdanningsdirektoratet, 2016). Både studenter 
og undervisere får prøve sine digitale ferdigheter gjennom å være deltaker i den digitale læringsressursen Inter-Dig, ved å tilegne seg faglige kunnskaper og ikke minst uttrykke egen kompetanse.

\section{Oppbygning av kapittelet}

Jeg starter med å presentere hvordan Inter-Dig ble til med utgangspunkt $\mathrm{i}$ et prosjekt. I det neste avsnittet setter jeg Inter-Dig i en pedagogisk kontekst og teoretisk referanseramme. Jeg beskriver så planleggings- og utviklingsprosessen av Inter-Dig, slik den foregikk gjennom ulike faser. Struktur og oppbygning presenteres, med fokus på pedagogiske og didaktiske vurderinger og begrunnelser. Jeg har valgt å dele diskusjonen i to hoveddeler, der jeg diskuterer læringsressursens oppbygning med utgangspunkt i to videoer satt i en pedagogisk kontekst. Jeg har valgt å føre diskusjonen fortløpende gjennom hele kapittelet, ved at jeg trekker inn relevant teori og egne refleksjoner underveis. Til sist oppsummerer jeg kapittelet og deler tanker om veien videre.

\section{Inter-Dig blir til}

Målet for prosjektet Inter-Dig var å styrke studentens kompetanse om tverrprofesjonell samarbeidslæring ved å prøve ut læringen på en digital læringsarena med digitale verktøy og digitale arbeidsformer. Et annet mål var å tilby en digital læringsressurs om tverrprofesjonell samarbeidslæring som et supplement i studieløpet, og som ga fleksibilitet i gjennomføring i tid og sted. Målgruppen var studenter ved alle 15 helseprofesjonsutdanninger ${ }^{1}$ ved UiT Norges arktiske universitet. Inter-Dig som fleksibel læringsressurs skulle også være tilgjengelig for studenter ved andre studiesteder som var geografisk spredt over hele NordNorge, ikke minst for dem som sjelden eller aldri møter andre studenter fra andre helseprofesjoner i løpet av sine praksisstudier. Denne fleksible læringsressursen skulle være et supplement til andre tverrprofesjonelle læringsaktiviteter tilrettelagt i studiets teori- og praksisundervisning. Utviklingen av Inter-Dig ble gjort i et samarbeid mellom lærere og studenter fra seks ulike studieprogram ved Det helsevitenskapelige fakultet ved UiT Norges arktiske universitet. Disse var

Bioingeniør, klinisk ernæring, tannpleie, tannlege, lege, jordmor, sykepleie, ergoterapi, paramedisin, farmasi, fysioterapi, psykologi, helsesykepleie, radiograf og vernepleie. 
tannlege-, tannpleier-, ergoterapeut-, sykepleier-, lege- og vernepleierutdanningen i samarbeid med Senter for helsefaglig pedagogisk utvikling (HelPed) ved UiT (Furu, 2018).

\section{Pedagogisk perspektiv og læringsdesign}

Den pedagogiske oppbygningen av Inter-Dig tar utgangspunkt i ulike perspektiver på læring. Dette kapittelet tar utgangspunkt i en teoretisk referanseramme som beveger seg mellom et sosiokulturelt perspektiv på læring og aktivtetsteori. Et sosiokulturelt perspektiv på læring framhever at læring først og fremst skjer i en sosial, kulturell og historisk sammenheng, i tillegg til den kognitive læringen. Utvikling og tenkning har sitt utgangspunkt i sosial aktivitet der læringen skjer i dialog og samspill mellom mennesker, og der tenkningen utvikles gjennom språklig samhandling (Vygotsky, 1987; Säljø, 2001; Dysthe, 2001). Aktivitetsteori handler om hvordan mennesket lærer gjennom å delta i aktiviteter, og at menneskets handlinger må forstås som et resultat av den historiske og kulturelle sammenhengen de er en del av (Vygotsky, 1987; Engeström, 2001). I disse perspektivene bringes begrepet mediert læring inn. Begrepet mediering kommer av det tyske ordet «vermittlung», som betyr å formidle, og antyder at mennesker ikke står i direkte, umiddelbar og ufortolket kontakt med omverdenen (Vygotsky, 1987; Säljø, 2001). Mediering handler om hvordan mennesker samhandler og bruker fysiske og intellektuelle redskaper (tools and signs), eller som i dette tilfellet, digitale verktøy, som støtte i læringsprosessen. Medierende artefakter kan også ses på som historiske og kulturelle artefakter (Engeström, 2001). I Inter-Dig benyttet studentene medierende verktøy som diskusjonsforum og samskriving via Office 365 som støtte for å lære tverrprofesjonelt samarbeid. Slik kan en forstå hvordan tenkningen utøves av studenter som handler i sosiale praksiser, ved hjelp av artefakter eller hjelpemidler.

Daniel Churchill (2017) sier at på en digital arena fremstår ikke digitaleverktøy som en erstatning for læreren, men et verktøy som kan fasilitere, muliggjøre og mediere læringsaktiviteter og bidra til å styrke studentenes opplevelse av mestring. Sosiokulturell læringsteori er spesielt opptatt av samspillet mellom redskaper og den lærende, og hvordan utviklings- og læringsprosesser kan oppstå i dette samspillet (Dysthe, 2001). I Inter-Dig ble casebasert læring valgt som pedagogisk arbeidsform. Casebasert læring fremheves som studentaktiviserende og engasjerende for læring og benyttes i dag i undervisningen ved flere helsefagutdanninger 
ved Helsefak. Churchill (2017) sier at digital læring kan være effektiv når den oppstår i en kontekst av aktiviteter som engasjerer studentene til problemløsning av autentiske og komplekse situasjoner/caser:

Design of a learning experience should focus on an activity (e.g. problem solving, projects and inquiries) that engage learning in knowledge construction through intellectual use of resource serving as mediating tools (Churchill, 2017, s. xvii).

Susan McLean (2016) sier at casebasert undervisning motiverer studentene til aktivitet gjennom felles kunnskapsbygging og konstruksjon av kunnskap rundt problemløsning av caser. Konstruksjon av kunnskap, konstruktivisme, tar utgangspunkt i teorier om hva kunnskap er, og gjennom aktivitet konstruerer menneskene kunnskap sammen (Vygotsky, 1987; Dewey, 1916). I et konstruktivistisk læringsmiljø blir det lagt til rette for at den som lærer, vurderer ny informasjon opp mot egen eksisterende kunnskap, slik at nye kunnskapsstrukturer bygges. Gjennom løsningen av caser etablerer studentene relasjoner og samarbeid i tverrprofesjonelle grupper og utfordrer hverandre i kommunikasjonen gjennom ulike aktiviteter der studentene benytter digitale verktøy. I samspillet, samhandlingen og dialogen via skriftlig kommunikasjon la vi til rette for at læringsprosesser kunne oppstå, og at studentene kunne lære av hverandre. I Inter-Dig ble digitale videocaser sentrum for studentenes aktiviteter og kunnskapsbygging. Diskusjonsforum og samskriving i Office 365 var skriftlige kommunikasjonsverktøy for felles aktiviteter, diskusjoner, problemløsning og beslutningstaking. I tillegg til å benytte digitale verktøy i Canvas ble det bygget nettsider/innholdssider om tverrprofesjonell samarbeidslæring med tekster, bilder og lenker, anbefalt litteratur og tilhørende læringsaktiviteter.

\section{Utviklingsprosessen og didaktiske vurderinger}

I arbeidet med å bygge opp en helt ny læringsressurs som skulle være digital, var det mange ulike pedagogiske valg og vurderinger som skulle tas. I planleggingen er didaktisk relasjonsmodell (Bjørndal \& Lieberg, 1978) og ASSURE-modellen (Heinich et al., 1999) til støtte for didaktiske vurderinger og valg. ASSURE-modellen (Instructional design model) er en modell 
til hjelp i planlegging og utvikling av undervisning der teknologi anvendes. Modellen benyttes oftest i utviklingen av hele emner eller kurs, men kan også være til god hjelp når læringsressurser utvikles. De ulike elementene i ASSURE-modellen er gjensidig avhengige av hverandre og må derfor vurderes i forhold til hverandre, slik at samstemthet ivaretas.

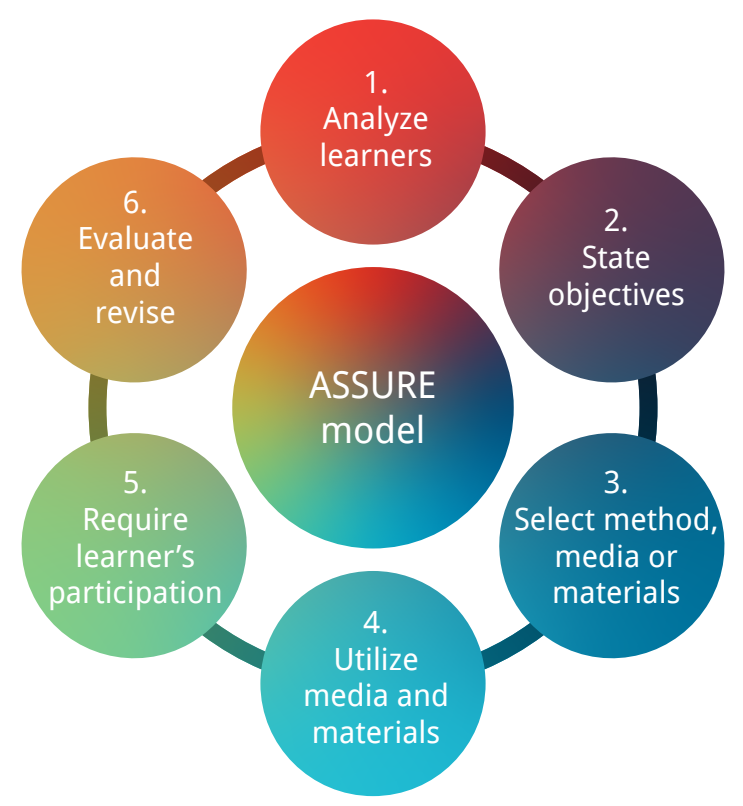

Figur 1 ASSURE-modellen (Heinich, Molenda, Russell \& Smaldino, 1999).

ASSURE-modellen illustrerer de ulike stegene i planleggings-, utviklings- og evalueringsprosessen:

A - Analyze learners (analysere målgruppa)

S - State standards and objectives (beskrive forventet oppnådd læringsutbytte)

$S$ - Select media, materials and methods (velge digitale verktøy, innhold og arbeidsformer)

U - Utilize Technology, Media, and Materials (ta i bruk teknologi, digitale verktøy og digitalt innhold)

$\mathrm{R}$ - Require Learner Participation (aktivisere studentene i læringsprosessen)

E - Evaluate and Revise (evaluere og utføre forbedringer) 
Gjennom de seks stegene viser modellen hvordan en analyserer, velger ut, anvender og evaluerer bruken av teknologi knyttet til læringsutbytte, målgruppe, innhold, læringsaktiviteter, arbeidsformer og vurderingsmetoder, som alle er viktige elementer i en systematisk designerprosess (Kim \& Downey, 2016). ASSURE-modellen har en positiv innflytelse på læringen hos studenter som har gjennomgått undervisning utviklet etter denne modellen (Kim \& Downey, 2016). Modellen støtter og motiverer til utvikling av studentsentrerte og studentaktive læringsressurser. Anvendelse av ASSUREmodellen i utvikling av digitale undervisningsressurser viser til at studentene oppnår økt læringsutbytte (Kim \& Downey, 2016).

Inter-Dig, fra idé til ferdig utviklet læringsressurs, ble til gjennom ulike faser som beskrives i det følgende gjennom planleggings-, utviklings-, utprøvings- og evalueringsfasen.

\section{Planleggingsfasen}

I denne fasen planla vi læringsressursens innhold, læringsaktiviteter, arbeidsog vurderingsformer og digitale samarbeidsverktøy med utgangspunkt i læringsutbyttene og målgruppas behov og forutsetninger. Alle delelementene i ASSURE-modellen ble vurdert i forhold til hverandre gjennom planleggingsprosessen.

\section{Utviklingsfasen}

I denne fasen ble læringsressursens struktur og pedagogisk design utviklet. Canvas ble valgt som digital læringsplattform med tilhørende digitale samarbeidsverktøy som var tilgjengelig: diskusjonsforum og dokumenter for samskriving. Manus ble utformet om pasienten Emma som trengte rehabilitering etter et brudd i foten, og en videocase ble produsert. En annen video om de ulike profesjonene som nylig var nylig utviklet ved Helsefak, ble benyttet i oppbygningen av første del av læringsressursen. De ulike nettsidene ble utviklet med tekster, video, bilder og lenker, og de ble satt sammen i en pedagogisk kontekst. De ulike læringsaktivitetene, oppgavene og innleveringene ble produsert og utviklet i Canvas. Helt til slutt ble evalueringsspørsmålene utformet $\mathrm{i}$ et digitalt evalueringsverktøy, nettskjema.uio.no, og det ble 
laget en lenke fra Canvas til nettskjemaet. Som et ledd i kvalitetssikringen av læringsressursen gjennomførte vi korrekturlesning og sjekket regler for universell utforming (uu.difi.no). Begge videoer ble tekstet på norsk og engelsk for å imøtekomme krav om universell utforming.

\section{Utprøvingsfasen}

Læringsressursen ble prøvd ut av 55 helsefagstudenter. I utprøvingsfasen samarbeidet studentene i tverrprofesjonelle grupper på nettet uten å møtes fysisk. Studentene ble rekruttert via studielederne ved de ulike studieprogrammene. For å sikre at studentene hadde forkunnskaper om egen profesjon og egen utdanning, ble det rekruttert studenter i hovedsak fra andre og tredje år ved bachelorutdanningen. I ethvert gruppearbeid er det viktig at studentene har tilstrekkelige forutsetninger for å bidra i diskusjonene, enten med en teoretisk bakgrunnsforståelse eller personlig erfaring (Biggs \& Tang, 2011).

Prosjektgruppa koordinerte rekrutteringsprosessen for å sikre at studentene ble rekruttert fra ulike studieprogram. For å delta i utprøvingen måtte studentene fylle ut et skriftlig samtykkeskjema der de samtykket i å levere to innleveringer og ei evaluering, og bruke minimum 15 timer til dette arbeidet fordelt over sju dager. Studentene fikk utbetalt et honorar etter å ha gjennomført læringsressursen i Canvas.

Det var et stort manuelt arbeid å sette sammen de tverrprofesjonelle gruppene. Til sammen ble ni tverrprofesjonelle grupper opprettet, med seks studenter i hver gruppe. Dette arbeidet kunne vært utført effektivt med et digitalt påmeldingssystem, der studentene selv kunne melde seg på den aktuelle tverrprofesjonelle gruppa de ønsket å delta i.

\section{Evalueringsfasen}

Etter at utprøvingen av Inter-Dig var over, besvarte studentene en omfattende obligatorisk evaluering. Evalueringsskjemaet bestod av 38 spørsmål som studentene besvarte skriftlig i nettskjema.uio.no. Spørsmålene ble utformet med åpne og lukkede spørsmål og var inndelt i tre hovedområder: faglig innhold, teknologi og pedagogiske verktøy og organisering og gjennomføring. Resultatene fra studentenes evaluering presenteres og diskuteres i 
kapittelet «Studentenes erfaringer fra deltakelse i en digital læringsressurs om tverrprofesjonelt samarbeid».

\section{Diskusjon: pedagogiske betraktninger om pedagogisk design}

I det følgende presenteres og diskuteres den pedagogiske oppbygningen av Inter-Dig.

\section{Individuelle oppgaver og samarbeidsoppgaver i Inter-Dig}

Hvilke læringsaktiviteter ville best støtte studentenes oppnåelse av læringsutbyttene? Vi valgte å utvikle både individuelle og kollektive oppgaver som støttet ulike perspektiver på læring; individuelle kognitive aktiviteter, sosiokulturelle aktiviteter og aktiviteter som oppstår i et virksomhetssystem (Vygotsky, 1987; Engeström, 1987). Resultatet ble to individuelle oppgaver og tre gruppeoppgaver som skulle løses i tverrprofesjonelle team. Målet for oppgavene var å stimulere til studentaktiv læring og tverrprofesjonelt samarbeid gjennom egenaktivitet, samarbeid og nettdiskusjoner.

Kognitivisme handler om å beskrive og forstå menneskets kognitive utrustning og dets mentale prosesser (Säljø, 2001), som vektlegger at individet ikke bare passivt tar imot informasjon, men at vi skaper vår egen forståelse i interaksjon med omverdenen. Vi er aktive mennesker og skaper meningsfulle enheter av det vi vier vår oppmerksomhet til. Gjennom utviklingen av «quiz» eller test i Inter-Dig kunne studenten utfordre eget kunnskapsnivå og forståelse ved å svare på ulike spørsmål og påstander til bearbeidelse, etterfulgt av automatiske tilbakemeldinger fra lærer. I et sosiokulturelt perspektiv på læring tas det utgangspunkt i samspillet mellom kollektive ressurser for tenkning og handling på den ene siden og individets læring på den andre, der kommunikasjon og språk er helt sentralt (Vygotsky, 1987). Vi utformet oppgaver som oppfordret til dette samspillet gjennom en utforskende tilnærming, ved at studenten stiller utdypende spørsmål til medstudenter og reflekterer over disse. Oppgavene utfordret også det tverrprofesjonelle samarbeidet med utgangspunkt i en pasientcase med studentenes felles diskusjoner, 
analyser og refleksjoner, og deres forhandlinger fram til felles forståelse. I samarbeid med studenter fra andre profesjonsutdanninger får studenten mulighet til å utvikle samhandlingskompetanse, i tillegg til å styrke egen profesjonskompetanse. Den tverrprofesjonelle læringen som oppstår i den sosiale interaksjonen, kan også bidra til personlig vekst i tverrprofesjonalitet.

\section{To videofilmer som utgangspunkt for læring}

Jeg har valgt å bygge opp kapittelet videre slik innholdet i læringsressursen ble strukturert, med utgangspunkt i de to videofilmene Profesjoner $i$ helsetjenesten og Case om Emma.

Med utgangspunkt i videofilmen Profesjoner $i$ helsetjenesten diskuterer jeg pedagogiske aspekter og begrunner disse. I utviklingen av læringsaktivitetene sørget vi for samstemthet (constructive alignment) mellom læringsutbytter, læringsaktiviteter og vurderingsformer (Biggs \& Tang, 2011). Et av læringsutbyttene var å «synliggjøre egen kompetanse og beskrive samarbeidende studenters kompetanse, roller og ansvar i en tverrprofesjonell samarbeidssituasjon om pasienten». Hvilke læringsaktiviteter og vurderingsformer bør velges for at studenten skal oppnå dette læringsutbyttet?

Læringsutbytte:

- Diskutere verdien av å ha kunnskap om hverandres profesjoner.

\section{Etablere et trygt læringsmiljø på en digital arena}

Hvordan bli kjent med hverandre på en nettbasert arena? Studentene kjente ikke hverandre på forhånd før de møttes i tverrprofesjonelle grupper i Canvas. Vi valgte derfor å gi studentene en utfordring allerede i den første individuelle oppgaven, der studentene skulle produsere sin egen video- eller lydfil, presentere seg selv og fortelle om egen profesjon. Lyd- og videosnuttene hadde en varighet på ca. to minutter og ble lagt ut gruppevis i Canvas, slik at alle studentene kunne se og høre hverandres presentasjoner. Hensikten var 
at studentene skulle bli bedre kjent med hverandre, og at det skulle bidra til å skape et trygt læringsmiljø på nettet (Garrison \& Anderson, 2003). Ved å produsere en video- eller lydfil om seg selv ble studentene utfordret både til å vise digitale ferdigheter, beskrive egen profesjons rolle og ansvar, og viktigst av alt, starte relasjonsbyggingen til sine medstudenter. Gode relasjoner mellom studenter og lærere og et trygt læringsmiljø er et godt utgangspunkt for å få til samarbeid og gode diskusjoner på nett (Garrison \& Anderson, 2003; Fossland, 2015). Video- og lydsnuttene ble benyttet som en «icebreaker» for at studentene skulle bli kjent med hverandre og bidra til å skape trygghet og tillit i det digitale forumet (Salmon, 2002). Studentene starter dermed prosessen med å bygge en relasjon til hverandre og blir bevisst egen profesjon og rolle. Først når et trygt læringsmiljø preget av respekt og tillit er etablert mellom studentene, og de kjenner hverandres roller og ansvar, er viktige forutsetninger lagt for å starte det digitale samarbeidet.

\section{Lære om egen og andre profesjoners rolle og ansvar}

Det tverrprofesjonelle samarbeidet ble igangsatt ved at vi laget en tverrprofesjonell oppgave som omhandlet de ulike profesjonene. Oppgaven gikk ut på å skrive et innlegg i diskusjonsforumet og foreslå hvilke observasjoner og tiltak som var nødvendige i den akutte situasjonen. Studenten ble oppfordret til å stille spørsmål til de andre profesjonene for å bli kjent med deres roller og ansvar. Ved å stille spørsmål til hverandre vedrørende handlingen i videofilmen ble studentene utfordret til refleksjon og til å knytte teori til praksis (McLean, 2016). Slik startet studentene med å bli kjent med hverandres profesjoner og diskutere verdien av å ha kunnskap om andres profesjoner.

Den andre individuelle oppgaven som ble laget i første del av læringsressursen, var en kunnskapstest, "profesjonsquizen», som ble utviklet for å teste studentenes kunnskaper om de ulike profesjonenes roller og ansvarsområder. Intensjonen med profesjonsquizen var at den skulle bidra til at studentene ble tryggere på egen og andre profesjoners rolle og ansvar. Vi valgte å lage en quiz fordi den stimulerer til aktiv deltakelse og kan motivere til læring. Churchill hevder at "Technology opens the opportunity for design, development and delivery of interactive visual material for the effective manipulation and exploration by learners engaged in an activity which results in the development of conceptual knowledge required for theoretical thinking» 
(Churchill, 2017, s. 139). «Theoretical thinking» bidrar til å utvikle studentens evne til kritisk tenkning, selvforståelse og selvutvikling (Churchill, 2017). En studentaktiviserende aktivitet som en quiz er, bidrar til at studenten tester egne teoretiske kunnskaper og samtidig trigges læringslysten gjennom konkurranse, nysgjerrighet og prestasjoner. Det er av stor betydning å lage en quiz med gode spørsmål og svar med konstruktive tilbakemeldinger som kan bidra til å styrke studentens forståelse. Studenten kan ta quizen flere ganger, med mulighet for korreksjon og repetisjon av faginnholdet. Profesjonsquizen responderte til studentene med poeng og med utfyllende og konstruktive svar gjennom automatiserte tilbakemeldinger fra lærer.

Med utgangspunkt i læringsutbyttene ble det utviklet faginnhold og læringsaktiviteter med utgangspunkt i videofilmen Case om Emma. I tillegg ble det utviklet nettsider med faginnhold relatert til tem og referanser til anbefalt litteratur. Et av læringsutbyttene var å kommunisere med samarbeidende studenter fra andre profesjoner. Hvordan kan en legge til rette for at studentene styrker sin samhandlingskompetanse på en digital arena, og hvordan kan casebasert læring bidra til å fremme personlig tverrprofesjonell vekst gjennom kommunikasjon og samarbeid? Disse aspektene diskuteres i neste avsnitt.

Læringsutbytte:

- Anvende eget fag i samarbeid med studenter fra andre profesjoner, pasienter og ev. andre samarbeidspartnere.

Læringsutbytte:

- Initiere, planlegge, gjennomføre, koordinere og evaluere eget arbeid med samarbeidende studenter og bidra til felles beslutninger i tverrfaglige team. 


\section{Casebasert læring bidrar til studentaktiv læring}

For å bygge et pedagogisk design som støtter oppunder læring med mange ferdighetsmål, ble casebasert læring valgt, med utgangspunkt i en reell videocase. McLean (2016) trekker fram casebasert læring som en pedagogisk arbeidsform som engasjerer studentene og bidrar til dybdelæring. Begrunnelsen for å velge casebasert læring som studentaktiv læringsform er at denne læringsformen engasjerer studentene til tverrprofesjonelt samarbeid gjennom kommunikasjon, samhandling, diskusjoner og refleksjoner, der alle profesjonene bidrar med egne kunnskaper for å løse pasientens problemstillinger. Casebasert læring (CBL) er en studentaktiv læringsform som tar utgangspunkt i en reell pasientsituasjon, og som inviterer til felles problemløsning for pasienten.

$\mathrm{CBL}$ is learning and teaching approach that aims to prepare students for clinical practice, through the use of authentic clinical cases. These cases link theory to practice, through the application of knowledge to the cases, and encourage the use of inquiry-based learning methods (Thistlethwaite, Davies, Ekeocha et al., 2012, s. 434).

I Inter-Dig ble casebasert læring tilrettelagt gjennom aktiv bruk av case som utgangspunkt for læring og samarbeid i tverrprofesjonelle team. I læringsplattformen Canvas ble det opprettet ni tverrprofesjonelle grupper der studentene arbeidet sammen. Oppgaveløsningen ble gjennomført ved å delta i interaktive diskusjoner og samskriving. Videocase om Emma ble utviklet med utgangspunkt i læringsutbyttebeskrivelsene og med fokus på å lære tverrprofesjonelle ferdigheter som roller og ansvar, teamwork, kommunikasjon, samarbeid og kritisk tenkning (Thistlethwaite, Davies, Ekeocha et al., 2012). Fagansatte og studenten i prosjektgruppa arbeidet med manus til en case med utgangspunkt i en reell pasientfortelling fra praksis. Casen ble omskrevet for å ivareta anonymisering og ble spilt inn av en fagansatt ved UiT og en pensjonist som skuespillere. Når skuespillerne hadde lest casen, spilte de ut rollene slik casen ga rom for. I utgangspunktet involverte casen noen få profesjoner, men ble videreutviklet til å omfatte flere problemstillinger og profesjonsområder, slik at studenter fra flere helseprofesjoner kunne involveres og delta $\mathrm{i}$ felles problemløsning. 


\section{Lære tverrprofesjonelt samarbeid på en digital arena}

Hvordan lære kommunikasjons- og samarbeidsferdigheter på en digital arena uten å møtes fysisk? Ulike læringsaktiviteter i Canvas hadde som formål å styrke studentenes ferdigheter som å samarbeide og kommunisere. De tverrprofesjonelle gruppene fikk i oppgave å utarbeide en tverrfaglig utskrivningsrapport som skulle innleveres i Canvas. I tillegg skulle gruppene lage forslag til individuell plan for pasienten, for til slutt å utarbeide et refleksjonsnotat over eget bidrag i gruppa og hvordan de opplevde at samarbeidet i gruppa hadde fungert. Refleksjonsnotatet skulle bidra til å styrke studentenes læring ved å sette ord på den tause kunnskapen som kan artikuleres gjennom både kropp, kultur, handling og språk (Molander, 1996).

Diskusjonsforum ble valgt som verktøy for å kommunisere digitalt. Diskusjonsforum gir mulighet for asynkron kommunikasjon, dvs. at dialogen foregår ikke i sann tid og er uavhengig av tid og sted (Fossland, 2015). Studentene skulle oppøve den skriftlige kommunikasjonen gjennom å benytte diskusjonsforum, som er et verdifullt verktøy for å formulere tekster og å analysere og reflektere over disse (Dysthe, 2001). I diskusjonsforumet kan studentene oppøve kommunikasjonsferdigheter som å stille spørsmål, argumentere, diskutere og reflektere. For å skape aktivitet i nettdiskusjoner kreves det at problemstillinger og oppgaver er motiverende og tilstrekkelig komplekse, slik at studentene må bruke tid på å reflektere over det de skriver (Fossland, 2015). Et annet aspekt er at en skrevet tekst i stor grad er overlatt til leseren og vedkommendes tolkninger (Säljø, 2001). I den skrevne teksten er kommunikasjonen enveis, og derfor er det av betydning at den som leser teksten, får mulighet til å stille utdypende spørsmål. I dialogen med hverandre kan studentene stille nye spørsmål, diskutere og analysere pasientens problemstillinger og forhandle seg fram til felles problemstillinger de ønsker å arbeide videre med. Den skriftlige kommunikasjonen i digitale diskusjoner preges ofte av lengre og bedre formulerte tekster (Dysthe, 2001), og derfor kan det virtuelle møtet gi bedre tid til refleksjon og dybdelæring. Diskusjoner på nettet bør legges opp med hensyn til forventet læringsutbytte, og det bør gis klare retningslinjer for hvordan gå fram i diskusjonen (Fossland, 2015). Gjennom dialogen og meningsbrytingen stimulerer studentene hverandre til et neste steg i tverrprofesjonell utvikling (Vygotsky, 1987; Engeström, 2001). 


\section{Hvordan oppstår læringsprosesser på en digital arena?}

Læring er knyttet til aktivitet og handling, også på en digital arena. Yrjö Engeström introduserer aktivitetsteori som en metode for å analysere og strukturere menneskets handlinger og aktiviteter innenfor en virksomhet, for eksempel på arbeidsplassen (Engeström, 1999, 2001). Innenfor et aktivitetssystem er motsetninger, spenninger og uenigheter i konstant bevegelse, og disse beskrives som et ledd i utviklings- og læringsprosesser, der den ekspansive læringen oppstår (Engeström, 1987). Gjennom de digitale diskusjonene og meningsutvekslingen kan studentene utfordre hverandre i dialogen. Ekspansiv læring involverer en kollektiv debattering, gjennom å stille spørsmål ved eksisterende rutiner og praksiser, analysere motsetninger, noe som krever forhandlinger over ulike perspektiver og konsepter (Engeström, 2010). Studentene representerer ulike profesjoner ved ulike praksiser og derav ulike virksomheter, og diskusjonene og forhandlingene med utgangspunkt i pasientcasen om Emma vil foregå i de digitale tverrprofesjonelle gruppene. Pasientcaser gir aktivitetene sammenheng og kontinuitet, mens spenningsfeltet som kan oppstå gjennom indre motsetninger, diskusjoner og forhandlinger om kunnskap, kan bidra til igangsetting av utviklings- og læringsprosesser.

\section{Casebasert læring fremmer dialog mellom studentene}

Med utgangspunkt i en case ble studentene oppfordret til å arbeide sammen i tverrprofesjonelle grupper og løse interaktive læringsaktiviteter. McLean (2016) hevder at casebasert læring (CBL) bidrar til å fremme selvstyrt læring, klinisk problemløsning, klinisk resonnering og beslutningstaking og kan engasjere studentene til aktive læringsprosesser. Studentene liker CBL, men det er vanskelig å si om hvorvidt dette er relatert til gruppeprosessen generelt eller CBL spesielt. Jill Thistlethwaite, David Davies, Samilia Ekeocha et al. (2012) sier at i forhold til hvor effektiv casebasert læring (CBL) er, så er det liten støtte i forskningen og ingen signifikant bekreftelse for dette. Endringer av holdninger eller kunnskap ses over tid, men det er vanskelig å si om casebasert læring bidro til dette alene, eller om det var andre årsaker, som eksempelvis andre undervisnings-/læringsmetoder. En kan derimot stadfeste at casebasert læring fremmer kommunikasjon gjennom gruppeprosessen og bidrar til 
interaksjon mellom studentene. Farzaneh Golaghaie, Shadi Asgari, Sharareh Khosravi et al. (2019) konkluderer i sin studie med at casebasert læring kombinert med refleksjonsgrupper i videreutdanning av sykepleiere hadde signifikant effekt på økt læringsutbytte både like etterpå og etter tre måneder, sammenlignet med tradisjonell klasseromsundervisning. I Inter-Dig ble studentene delt inn i tverrprofesjonelle grupper, og hver gruppe ble tildelt eget grupperom i Canvas. Her kunne de diskutere og reflektere sammen innenfor trygge rammer og bygge et godt samarbeidsklima for læring.

Casebasert læring (CBL) hjelper studentene til å knytte kunnskap til daglig praksis, styrke egen rolle gjennom å vise kognitive kunnskaper, egne ferdigheter og holdninger i en situasjon (McLean, 2016). Likeså skaper casebasert læring kreativitet, fremmer kritisk tenkning, utfordrer og skaper interesse og glede, stimulerer til akademisk utfordring og øker personlig interesse og involvering i situasjonen. Arbeidsformen bidrar til å være selvkritisk og til å se egne begrensninger, som igjen kan bidra til kontinuerlige forbedringer. En studie av Hilde Marie Andreassen og Tove Lisbeth Holmsen (2018) om casebasert læring i utdanning av sykepleiere anbefaler CBL som metode for videre utvikling av kritisk tenkning og refleksjon gjennom en problemløsende tilnærming. Gjennom studentenes samspill og dialog i Inter-Dig kan refleksjon og kritisk tenkning fremmes gjennom felles problemløsning om pasientens utfordringer. Vi la til rette for at studentene deltok i digitale refleksjonsgrupper i Inter-Dig og vurderte å etablere fysiske refleksjonsgrupper i tillegg. Fordi læringsressursen ikke var organisert som en del av et studieprogram eller emne, var det vanskelig å finne tilgjengelige lærer- og veilederressurser som kunne tilrettelegge og veilede studentene i fysiske refleksjonsgrupper.

\section{Lærerens digitale kompetanse}

Et av målene med Inter-Dig var at læringsressursen skulle utvikles og designes på en slik måte at den framsto med kvalitet og bidro til å fremme studentens læring. I hvilken grad vi har lyktes med dette, kan resultatene fra evalueringen av læringsressursen gi noen tilbakemeldinger om. Hvilken betydning har lærernes digitale kompetanse hatt i utviklingen av Inter-Dig? Vi har ingen evalueringer fra fagpersonene som bidro i utviklingen av Inter-Dig, men ytterligere forskning kan muligens gi noen flere svar. Min oppsummering er at fagpersonenes pedagogiske og digitale kompetanse har vært viktig 
og betydningsfull i utviklingen av Inter-Dig, både med tanke på pedagogiske valg og didaktiske vurderinger i oppbygging og valg av digitale verktøy.

Hva forstår vi med lærerens profesjonsfaglige digitale kompetanse? Profesjonsfaglig digital kompetanse omfatter mye mer enn å undervise ved å benytte digitale læringsressurser og teknologier. Det innebærer at læreren må forstå sammenhengen mellom samfunnet, læring og teknologi. Det handler også om at læreren utøver selvstendighet og dømmekraft i valg og bruk av digitale ressurser, og at lærer har kunnskap om nye måter å forstå lærerrollen, studentrollen og undervisning på (Utdanningsdirektoratet, 2016). Rune J. Krumsvik (2014) sier at det er ikke nok å lære seg basisferdigheter om hvordan teknologien fungerer, men like viktig er å ha kunnskaper om hvordan anvende teknologien i en pedagogisk kontekst. Lærer må også ha kunnskap om hvordan studentene lærer, dvs. ulike læringsteorier, læringsprosesser og læringsstrategier og vite hva som motiverer studentene til læring. Lærerens digitale kompetanse i lærerutdanningen uttrykkes slik:

Teacher education today needs to consider the pedagogical use of ICT and digital competence in order to prepare student teachers for practice, but also in order to develop a narrower definition of digital competence on an individual level (micro level) and what this means for student teachers' learning during their teacher education (Krumsvik, 2014, s. 273).

Et viktig spørsmål for utvikling av felles digitale læringsressurser er: Hvordan bygge opp læringsressursen med digitalt innhold og bruk av digitale verktøy som i den aktuelle konteksten best fremmer studentens læring? Digital kompetanse handler ikke bare om å fremme mulighetene for pedagogisk bruk av IKT, men også om å diskutere og reflektere over etiske utfordringer og datasikkerhet ved bruk av teknologi. Trine Fossland (2015) sier at digital kompetanse i høyere utdanning involverer faglige og praktiske kunnskaper, ferdigheter og generell kompetanse knyttet til anvendelse og tilrettelegging av digital teknologi. Dette omfatter å kritisk vurdere læringsressurser og produsere digitalt innhold, der læringsaktivitetene og vurderingsformene er hensiktsmessige for studentens lærings- og danningsprosess. Undersøkelsen Digital tilstand, som omhandler perspektiver på digitalisering for læring i høyere utdanning, konkluderer med at det er behov for å styrke fagansattes digitale kompetanse. Dette innebærer en tettere kobling mellom pedagogiske, 
teknologiske, organisatoriske og kompetanserelaterte dimensjoner i arbeid med digitalisering av læringsprosesser og kvalitetsutvikling i høyere utdanning (Diku, 2019). Et sentralt funn i undersøkelsen er at kompetansebygging for fagansatte bør være tett knyttet til deres arbeid med utvikling av undervisnings- og læringsaktiviteter for studentene. Min oppsummering er at lærernes kompetanse har økt i arbeidet med pedagogisk, didaktisk og digital tilrettelegging av Inter-Dig. Kompetanseøkningen kan forstås ved «boundary crossing», ved å krysse grenser til ukjente fagområder for å søke hjelp og gi hjelp, og sammen skape et nytt konsept (Engeström \& Sannino, 2010). Studentenes involvering og medvirkning i alle faser av utviklingen har også bidratt til å styrke læringsressursens kvalitet. Læring er en aktiv prosess som styrer samspill og samproduksjon mellom studenter og undervisere og studenter imellom (Meld.St., 2016-2017).

\section{Avslutning}

Utviklingen av Inter-Dig har ikke bare fått meg til å reflektere over mulighetene teknologien gir, men også over de begrensningene som teknologien utfordrer oss på når helsefagstudenter skal lære tverrprofesjonelt samarbeid. Mitt spørsmål er fortsatt om det er mulig å lære samhandlingskompetanse på en digital arena uten å møtes fysisk? De pedagogiske valgene og de digitale verktøyene som ble benyttet i utviklingen av Inter-Dig, vil ha innflytelse på studentenes oppnådde læringsutbytte, men det må mer forskning til for å forstå hvordan læringsprosesser oppstår i digitale læringsmiljø, og om samhandlingskompetanse kan læres på en digital arena alene.

Som organisasjon har vi lært at lærerens digitale kompetanse har stor betydning i digitalisering av undervisning, og ikke minst har den betydning for studentenes måloppnåelse, lærings- og mestringsopplevelse. Undervisers digitale kompetanse og kunnskap om pedagogisk bruk av teknologi i undervisning er viktig og nødvendig når nye digitale læringsressurser utvikles. Studentinvolvering fra start til slutt i utviklingsprosessen sikrer brukermedvirkning, og med studentene på laget kan en bedre imøtekomme studentenes behov og sikre at læringsutbyttene oppnås. Digital dømmekraft og digital sikkerhet er aspekter som både lærere og studenter bør ha kunnskap om når teknologi anvendes i undervisning og læring. Digitaliseringen påvirkes også 
av organisatoriske, sosiale og kulturelle faktorer og prosesser. Det er av stor betydning at digital teknologi benyttes med kløkt og varsomhet i helsefagutdanningene og i de kontekstene der det er mest hensiktsmessig, og som bidrar til merverdi for studentens læring.

For framtiden bør det forskes mer på forholdet mellom profesjon, teknologi og pedagogikk, og undersøke hvordan undervisere tilrettelegger og anvender digital teknologi i undervisning, og hva som skjer med læringsprosessen i spenningsfeltet mellom disse. Hvilken betydning har lærerens digitale og utdanningsfaglige kompetanse for utvikling av undervisningskvalitet i høyere utdanning? Hvordan påvirkes læring og undervisningskvalitet i forholdet mellom teknologi og sosial kompleksitet i helse- og velferdstjenesten? Det ville også være interessant å undersøke nærmere betydningen av lærerens digitale og utdanningsfaglige kompetanse for å veilede, støtte, motivere og engasjere studenten i digitale læringsprosesser.

En stor takk rettes til studenter, lærere, fagansatte, Senter for helsefaglig pedagogisk utvikling (HelPed) ved Det helsevitenskapelige fakultet, UiT Norges arktiske universitet, Ressurssenter for undervisning, læring og teknologi (Result) ved UiT og alle andre som deltok i utviklingen av Inter-Dig.

\section{Referanser}

Alexander, B., Ashford-Rowe, K., Barajas-Murphy, Dobbin, G., Knott, J., McCormack, M., Pomerantz, J., Seilhamer, R. \& Weber, N. (2019). Educause Horizon Report: 2019 Higher Education Edition. Louisville, CO: Educause. $<$ https://library.educause.edu/-/media/files/library/2019/4/2019horizonreport. pdf?la=en\&hash=C8E8D444AF372E705FA1BF9D4FF0DD4CC6F0FDD1>. Hentet 15.10.21.

Andreassen, H.M. \& Holmsen, T.L. (2018). Case-based learning in nursing education. Vitenskapelig produksjon. <https:/www.idunn.no/nsf/2018/03/casebased_learning_in_nursing_education>. Hentet 15.10.21. 
Biggs, J. \& Tang C. (2011). Teaching for Quality Learning at University. London: Society for Research into Higher Education \& Open University Press.

Bjørndal, B. \& Lieberg, S. (1978). Nye veier i didaktikken. En innforing i didaktiske emner og begreper. Oslo: Aschehoug.

Churchill, D. (2017). Digital Resources for Learning. Hong Kong: Springer Texts in Education.

Det helsevitenskapelige fakultet (2019). Strategi for Det helsevitenskapelige fakultet (Helsefak) UiT mot 2022. <https://uit.no/Content/669432/ cache $=20202702152529 /$ Strategi $\% 20$ for $\% 20$ Det $\% 20$ helsevitenskapelige $\% 20$ fakultet.pdf>. Hentet 15.10.21.

Diku, Direktoratet for internasjonalisering og kvalitetsutvikling i høyere utdanning. (2019). Digital tilstand 2018. Perspektiver på digitalisering for læring i høyere utdanning. Rapportserie nr. 6/2019.

Dewey, J. (1916). Democracy and Education. United States: Kessinger Publishing`s Rare Reprints.

Dysthe, O. (red.). (1999). Ulike perspektiv på laring og laringsforskning. Oslo: Cappelen Akademisk Forlag AS.

Dysthe, O. (red). (2001). Dialog, samspel og laring. Oslo: Abstrakt Forlag AS. Engeström, Y. (1987). Learning by expanding. An activity-theorethical approach to developmental research. Helsinki: Orienta-Konsultit Oy.

DOI: https://doi.org/10.3868/s110-006-017-0011-8

Engeström, Y., Miettinen, R. \& Punamäki, R.L. (red.). (1999). Perspectives on activity theory. San Diego: Cambridge University Press.

Engeström, Y. (2000). Activity theory as a framework for analyzing and redesigning work. Ergonomics Vol. 43 (7), s. 960-974.

DOI: https://doi.org/10.1080/001401300409143

Engeström, Y. (2001). Expansive Learning at Work: toward an activity theoretical reconceptualization. Journal of Education and Work, 14 (No 1), s. 133-156. DOI: https://doi.org/10.1080/13639080020028747

Engeström, Y. \& Sannino, A. (2010). Studies of expansive learning: Foundings, findings and future challenges. Educational Research Review, 2010-01, 5 (1), s. 1-24. DOI: https://doi.org/10.1016/j.edurev.2009.12.002

Fossland. T. (2015). Digitale laringsformer i høyere utdanning. Oslo: Universitetsforlaget.

Furu, R. (2018). Inter-Dig - En digital læringsressurs om tverrprofesjonell samarbeidslæring. Prosjektbeskrivelse 041218. Senter for helsefaglig pedagogisk utvikling. Det helsevitenskapelige fakultet, UiT Norges arktiske universitet. 
Furu, R. (2019). Sluttrapport Inter-Dig. - En digital arena for tverrprofesjonell samarbeidslæring. Senter for helsefaglig pedagogisk utvikling. Det helsevitenskapelige fakultet, UiT Norges arktiske universitet.

Garrison, D. R., Anderson, T. (2003). E-Learning in the 21th Century. A Framework for Research and Practice. London and New York: Routhledge Falmer Taylor \& Francis Group. https://www.taylorfrancis.com/books/ mono/10.4324/9780203166093/learning-21st-century-randy-garrison

Golaghaie, F., Asgari, S. Khosravi, S. et al. (2019). Integrating case-based learning with collective reflection: outcomes of interprofessional continuing education. Reflective Practice. International and Multidisciplinary Perspectives. ISSN: 1462-3943 (Print). DOI: https://doi.org/10.1080/14623943.2018.1539660

Hauksdottir, N. \& Iversen, A. (2020). Tverrprofesjonell samarbeidslæring på Helsefak. Rapport fra Fyrtårnprosjekt 2016-2019. Senter for helsefaglig pedagogisk utvikling. Det helsevitenskapelige universitet. UiT Norges arktiske universitet.

Heinich, R., Molenda, M., Russell, J. D. \& Smaldino, S. (1999). Instructional media and technologies for learning (6. utg.). Englewood Cliffs, NJ: Merrill/ Prentice Hall.

Kim, D. \& Downey, S. (2016). Examining the Use of the ASSURE model by K-12 teachers. Computers in the schools. Interdisiplinary Journal of Practice, Theory and Research, 33, 2016. 3. utgave.

DOI: https://doi.org/10.1080/07380569.2016.1203208

Krumsvik, R. J. (2014). Teacher educater`s digitale competence. Scandinavian Journal of Educational Research, (58)(3), s. 269-280., Routhledge Taylor \& Francis Group. DOI: https://doi.org/10.1080/00313831.2012.726273

Kunnskapsdepartementet (2017). Digitaliseringsstrategi for universitetsog høyskolesektoren 2017-2021. <https://www.regjeringen.no/ contentassets/779c0783ffee461b88451b9ab71d5f51/no/pdfs/ digitaliseringsstrategi-for-universitets--og-hoysk.pdf>. Hentet 15.10.21.

Kunnskapsdepartementet (2017). Nasjonale retningslinjer for helse- og sosialfagutdanningene (RETHOS). <https://www.regjeringen.no/no/tema/ utdanning/hoyere-utdanning/utvikling-av-nasjonale-retningslinjer-for-helse--ogsosialfagutdanningene/om-retningslinjene/id2569505>. Hentet 15.10.21. 
Molander, B. (1996). Kunskap i handling. Göteborg: Bokförlaget Daidalos AB.

McLean, S. F. (2016). Case-Based Learning and its Application in Medical and Health-Care Fields: A Review of Worldwide Literature. J Med Educ Curric Dev. Jan-Dec; 3: JMEDCD.S20377.

DOI: https://doi.org/10.4137/JMECD.S20377

Meld. St. 16 (2016-2017). Kultur for kvalitet i høyere utdanning.

Kunnskapsdepartementet 2016. <https://www.regjeringen.no/no/dokumenter/ meld.-st.-16-20162017/id2536007>. Hentet 15.10.21.

Salmon, G. (2000). E-moderating: The key to teaching and learning online. London: Kogan Page.

Säljø, R. (2001). Laring i praksis. Et sosiokulturelt perspektiv. Oslo: Cappelen Akademisk Forlag.

Thistlethwaite, J.E., Davies, D., Ekeocha, S. et al. (2012). The effectiveness of casebased learning in health professional education. A BEME systematic review:

BEME Guide No. 23. DOI: https://doi.org/10.3109/0142159X.2012.680939

UiT Norges arktiske universitet (2018). Strategi for det helsevitenskapelige

fakultet (Helsefak). UiT mot 2022. <https://uit.no/Content/669432/

cache $=20202702152529 /$ Strategi $\% 20$ for $\% 20$ Det $\% 20$ helsevitenskapelige $\% 20$

fakultet.pdf>. Hentet 15.10.21.

Utdanningsdirektoratet (2016). Digitale ferdigheter som grunnleggende ferdigheter.

Fra rammeverk for grunnleggende ferdigheter. <https://www.udir.no/laringog-trivsel/rammeverk/rammeverk-for-grunnleggende-ferdigheter/2.1-digitaleferdigheter>. Hentet 15.10.21.

Vygotsky, L. S. (1987). Mind in Society. The Development of Higher Psychological Processes. Cambridge, Massachusetts, London, England: Harvard University Press. 